\title{
Politeness as a feature: so important and so rare*
}

\author{
Greville G. Corbett (Surrey, UK)
}

\begin{abstract}
Politeness has a major place in many languages, and is remarkably pervasive in some. Yet we rarely find respect as a morphosyntactic feature, alongside gender, person, number and case. I document this imbalance, and then ask why this is what we find.
\end{abstract}

\section{$1 \quad$ Introduction}

Politeness has a major place in many languages, and is remarkably pervasive in some. Yet we rarely find respect as a morphosyntactic feature, alongside gender, person, number and case. I document this imbalance, and then ask why this is what we find.

\section{The expression of politeness}

Politeness is expressed through a variety of linguistic means. Polite use of pronouns is well known, as in languages like French and Russian. Helmbrecht (2005) took a world sample of 207 languages, and found a politeness distinction in the pronoun in 64 of them. There are various names and titles which vary according to politeness requirements, from formal official titles through to nicknames. Then we find either special lexical items, or else morphological modifications of lexical items, which show respect (honorifics and humilifics). These are particularly prevalent in south-east Asia; a spectacular system is that of Javanese (Geertz 1960). And then there are various types of partial or complete avoidance: replacement of imperatives by 'softer' alternatives; avoidance of pronouns and combinations of pronouns (Heath 1991, 1998), avoidance of the name of important persons or deceased persons (see Foley 1986: 42 for examples from Papuan languages). Treis (2005) documents ballishsha in Kambaata; according to this tradition, married women avoid not only the names of their in-laws but also any word which begins with the same consonant and vowel (irrespective of vowel length). Avoidance in some language communities goes right up to avoiding talking at all to particular potential interlocutors or using special ('mother-in-law') language when doing so (Dixon 1980: 58-65).

Of the many examples of polite usage, let us take just one here: let us consider the polite imperative in the Daghestanian language Archi: ${ }^{1}$

\footnotetext{
* The support of the European Research Council (grant ERC-2008-AdG-230268 MORPHOLOGY) is gratefully acknowledged. Versions of this paper were read at the Southeast Morphology Seminar, University of Surrey, 20 February 2009, in the Arbeitsgruppe "Formen des Ausdrucks von Höflichkeit/Respekt im Gespräch: Reden über Dritte in verschiedenen Sprachen und Varietäten" at the 31st Annual Meeting of the Deutsche Gesellschaft für Sprachwissenschaft, Osnabrück, 6 March 2009, and in the Department of Linguistics, SUNY Stony Brook, 26 March 2009. I thank all these audiences for their helpful comments, especially Bob Hoberman and Richard Larson, as well as Penny Everson and Claire Turner for help in the preparation of the paper. Special thanks are due to Yvonne Treis and Silvia Zaugg-Coretti for generously sharing their data with me, and to an anonymous referee for useful suggestions. Much of the material presented here will be incorporated in revised form in Corbett (forthcoming).
} 
Archi (Marina Chumakina, personal communication)

$\begin{array}{lllll}\text { (1) } & \text { kuvsaro :t } & \text { čij } & \text { eca-su } & \text { gudum-mu-s } \\ & \text { kavsarat.VOC } & \text { tea(IV)[ABS.SG] } & \text { pour.IV.SG.IMP-HON } & \text { that.one.I.SG-OBL.SG-DAT }\end{array}$

'Kavsarat, please pour him some tea.'

Thus we have a marker $-s u$, which is purely for politeness; it is reserved for imperatives and prohibitives. $^{2}$

If we turn to function, and ask how the politeness is 'allotted', we find that these systems can be worked out along three main axes, the speaker-addressee axis, the speaker-referent axis and the speaker-bystander axis (Comrie 1976); Levinson (1979: 207) adds the speaker-setting axis (see also Brown/Levinson 1987: 180-182). There may be complex conditions on the choice of particular forms. Thus Mansi (a Finno-Ugric language spoken along the Ob river in Russia, by just over 3000 people at the last census) has special forms for polite commands, which are used for addressing a specially respected or older person, when a woman addresses a man who is older than her husband, and when addressing a spirit or a bear (Rombandeeva 1973: 127). ${ }^{3}$ Linguists have been aware of the problems: just for Japanese we find whole books on the topic, including by O'Neil (1966), Alpatov (1973) and more recently Wetzel (2004). However, these problems of usage are not the issue here, since our focus is on morphosyntactic features.

It is worth pointing out, however, that effects of this concern for politeness are not all positive. Using plural pronouns for a single addressee can lead to confusion. Take for instance, this example from Chekhov's Ty $i$ Vy (You.SG and you.PL) published in 1886. The humour is built round problems of incompatible systems of address; the questioner is an investigator, the respondent a peasant. The confusion and the humour are created by the two interlocutors investigator and peasant - having different address systems: the investigator has plural for politeness in the second person, but does not easily address the peasant politely. The peasant has plural in the first person, as a politeness strategy; he responds with my 'we' to a direct question about whether he understands:

\footnotetext{
${ }^{1}$ I use the Leipzig Glossing Rules, and have modified others' abbreviations to match the Leipzig Glossing Rules where possible: $\mathrm{ABS}=$ absolutive, CAUS = causative (CAUS1 is the 'single' causative), $\mathrm{CVB}=$ converb, DAT $=$ dative, $\mathrm{DECL}=$ declarative, $\mathrm{DEM}=$ demonstrative, $\mathrm{DIMIN}=$ diminutive, $\mathrm{F}=$ feminine, $\mathrm{G} 7=$ gender $7, \mathrm{GNRC}=$ generic, $\mathrm{IMP}=$ imperative, $\mathrm{IPFV}=$ imperfective, $\mathrm{M}=$ masculine, $\mathrm{OBL}=$ oblique, $\mathrm{PFV}=$ imperfective, $\mathrm{POSS}=$ possessive, $\mathrm{PROX}=$ proximal, $\mathrm{REFL}=$ reflexive, $\mathrm{SBJ}=$ subject, $\mathrm{VOC}=$ vocative; the following are additional to those in the Leipzig Glossing Rules: CNTR = contrastive, DS = different subject, HON = honorific, polite, IV = gender IV, PRON = pronoun.

2 It is also used with hortatives, which are formed using an original imperative, to which -su attaches (Kibrik 1977: 222-223, Marina Chumakina, personal communication).

3 There can be complex choices in the pronominal system. Thus San Lucas Quiaviní Zapotec has a six-way distinction in the third person pronouns, with respect playing a role in the choice (Munro 2002).
} 
(2)

\begin{tabular}{|c|c|c|c|c|c|c|}
\hline $\begin{array}{l}\text { Nužno } \\
\text { necessary }\end{array}$ & $\begin{array}{l}\text { govorit' } \\
\text { say }\end{array}$ & $\begin{array}{l}v y \ldots \\
2 \mathrm{PL}\end{array}$ & $\begin{array}{l}\text { Nel'́zja }^{\prime} \\
\text { Must.not }\end{array}$ & & $\begin{array}{l}\text { kat'! } \\
\text { se.thou }\end{array}$ & $\begin{array}{ll}\text { Esli } & \text { ja } \\
\text { if } & 1 \mathrm{sc}\end{array}$ \\
\hline govorju & tebe... & vam & $v y$, & to & vy & $\mathrm{i}$ \\
\hline say & 2SG.DAT & 2PL.DAT & $2 \mathrm{PL}$ & then & $2 \mathrm{PL}$ & EMPH \\
\hline $\begin{array}{l}\text { odavno } \\
\text { ee.more }\end{array}$ & $\begin{array}{l}\text { dolžny } \\
\text { must }\end{array}$ & $\begin{array}{l}\text { vežli } \\
\text { polit }\end{array}$ & & & & \\
\hline
\end{tabular}

Ono konečno, vašeskorodie! Nešto my ne ponimaem?

that of.course your.worship really 1PL NEG understand

$\begin{array}{lllll}\text { No } & \text { ty } & \text { slušaj, } & \text { čto } & \text { dal’̌se } \ldots \\ \text { But } & \text { 2SG } & \text { listen.IMP } & \text { what } & \text { further ... }\end{array}$

'It is necessary to say you (polite). It is not permitted to say thou. If I say thou ... you to you, then you all the more so must be polite!'

'Yes of course, your Worship! Do you really think we don't understand? But thou listen to what happened next...'

Furthermore, avoiding particular items is not conducive to smooth communication. More specifically, the particular desire to avoid dangerous combinations of persons (first person subject with second person object, or the opposite) lead to a variety of principles of 'pragmatic disguise' (Heath 1991, 1998), and eventually to restructurings of paradigms (as in Dalabon: Evans/Brown/Corbett 2001); see also $\$ 3.1$ below for other impacts of polite language.

\section{$3 \quad$ Morphosyntactic features}

I adopt a strict definition of 'morphosyntactic feature', according to which such a feature must be relevant both to morphology and to syntax. I distinguish such features from morphosemantic features, which are semantically charged and are reflected in morphology, but are not relevant in syntax; tense and aspect are often of the morphosemantic type. In contrast, on the strict definition, at least some of the values of a morphosyntactic feature must be distributed according to syntactic constraints (agreement or government). Typical examples are gender and person.

A second distinction is between a feature and a condition on a feature. To see the distinction let us consider German. German clearly has a number feature: this feature is relevant for morphology, and also for syntax, for rules of agreement, and hence qualifies as a morphosyntactic feature. Now let us look at predicate agreement with conjoined noun phrases in German. There is in principle a choice, since we find both singular and plural predicates in this situation:

German (Findreng 1976: 159)
Heide und
Moor dehn-en
sich endlos
weit. heath and moor stretch-PL
REFL endlessly
far
'Heath and moor stretch into the endless distance.'

$$
\begin{aligned}
& \text { daß wieder Zucker und Kaffee herauskam. } \\
& \text { that again sugar and coffee } \\
& \text { 'that sugar and coffee came out again.' }
\end{aligned}
$$

The main target factors which influence the choice of agreement are precedence and animacy: if the agreement controller precedes the target (the predicate) this favours plural agreement, 
and if the controller is animate this also favours resolution. This is demonstrated by the data in (5), calculated from Findreng (1976: 145, 165-166, 197). The table shows, for instance, that there were 1095 examples of conjoined noun phrases which denoted animates and which preceded the predicate; of these $96 \%$ had a plural predicate.

Agreement with conjoined noun phrases in German

\begin{tabular}{|l|c|c|c|c|}
\cline { 2 - 5 } \multicolumn{1}{c|}{} & \multicolumn{2}{c|}{ animate } & \multicolumn{2}{c|}{ inanimate } \\
\cline { 2 - 5 } \multicolumn{1}{c|}{} & $\mathrm{N}$ & $\% \mathrm{PL}$ & $\mathrm{N}$ & $\% \mathrm{PL}$ \\
\hline subject-predicate & 1095 & 96 & 1702 & 67 \\
\hline predicate-subject & 379 & 93 & 925 & 40 \\
\hline
\end{tabular}

It is evident from (5) that if the controller stands before the target, and if it denotes animates, these conditions indeed favour plural agreement (this is not something specific to German, but is found more generally, see Corbett 2000: 199-203). Clearly animacy has a role here. But we would not argue that animacy is a morphosyntactic feature in German: it has no direct role in the syntax or in the morphology. Rather it is a matter of lexical semantics, which acts as a condition on the use of the values of the morphosyntactic feature number.

From this perspective, we see that politeness is frequently expressed by conditions on the use of other morphosyntactic features. For instance, it is a condition on number in Russian, where the plural value is used for polite address. And it is not only the plural which can be specified (see Corbett 2000: 224-227 for the use of other number values for politeness in various languages). Politeness is a condition on person in Italian (where the third person is used for politeness). In the Daghestanian language Lak, it is a condition on gender. For data see Corbett (1991: 24-26) and the sources given there, especially Khaidakov (1980: 204-13). Lak has a four-gender system: male rational, female rational, animate (and many inanimates), and the residue (a few animates, some inanimates including most abstracts). Significantly, however, the noun $d u s ̌$ 'girl, daughter' was in gender III, not the expected gender II. Gender III agreements then became a sign of politeness when addressing young women (Khaidakov 1963: 49-50), particularly those earning their own living, and nouns denoting them have transferred to gender III. The convention has been extended so that now any woman outside the immediate family will be addressed using gender III agreements. Within the family older women such as ninu 'mother' and $а т и$ 'grandmother' are still addressed using gender II forms, for younger ones such as s:u 'sister' gender III is used. For referring to older women, gender II is still used; nevertheless the number of nouns in this gender has been significantly reduced.

Thus in these languages there is no justification for postulating an additional morphosyntactic feature respect. Rather politeness introduces complexity into the use of a different morphosyntactic feature.

\subsection{When respect is not a morphosyntactic feature}

Even when respect is not a morphosyntactic feature, but only a condition on a morphosyntactic feature, it can still have substantial effects. One well-studied effect is that of the agreement 
in number with polite pronouns. There is a conflict between the formal number of the pronoun (plural) and the 'real' number of the addressee (singular). This leads to the use of the plural for some targets, the singular for others, with a degree of uncertainty at the margin (Comrie 1975; Corbett 1983: 51-56, 2006: 230-233).

A contrasting example of morphosyntactic complexity involving respect, unusually for familiar address, is found in Basque. Here we find the allocutive, which involves the addition of an apparently spurious argument, with attendant changes in the verb inflection (see Baerman 2006 for the detail, following Hualde/Oyharçabal/Urbina 2003).

\subsection{Disputed cases}

There are instances where RESPECT has been treated as a morphosyntactic feature by some, while alternative analyses have been proposed by others. It was perhaps natural to try to treat repeated instances of politeness as instances of agreement, but these prove relatively unusual. Boeckx/Niinuma (2004) treat Japanese honorification as agreement, while Bobaljik/Yatsushiro (2006) argue against. There has been particular attention to Korean: Pollard/Sag (1994: 96-101) treat politeness in terms of agreement, while others have preferred alternative possibilities. Thus Choi (2003) considers the data from conjoining and argues for a pragmatic account. The most careful analysis is that of Kim/Sells (2007), following an earlier paper (Kim/Sells/Yang 2006). ${ }^{4}$ At first sight, an agreement analysis (using a morphosyntactic feature RESPECT) appears plausible, given examples like this one:

Korean (Kim/Sells 2007: 309)

(6) ape-nim-kkeyse mence ka-si-ess-ta

father-HON-HON.SBJ first go-HON-PAST-DECL

'Father went first.'

The honorific marker nim indicates that 'the speaker recognizes that the referent of the host noun is socially superior to himself/herself.' (Kim/Sells 2007: 308). Then we find kkeyse, which is both an honorific (again indicating that the speaker recognizes the social superiority of the referent) and an indicator of subject. When kkeyse occurs, the predicate typically also takes honorific marking with $(u) s i$. This might suggest an agreement analysis. This is not the only option, however. Kkeyse shows a level of extreme deference; it would therefore be pragmatically infelicitous to show extreme deference at one point in the utterance followed by a lack of deference which would be indicated by a verb without $(u) s i$. In other words, the two markers have a common external motivation, rather like particular stylistic indicators being maintained through an utterance. Kim/Sells (2007) argue convincingly that an agreement analysis is the wrong approach. First, honorific marking on the noun phrase and on the verb mean different things: the honorific on the noun phrase elevates the referent relative to the speaker, while that on the verb elevates the referent relative to the hearer (Kim/Sells 2007: 310). Contrast this with typical subject-predicate agreement in number (not honorific), where the agreement marker on the predicate indicates the number of referents (and not the number of events), just as on the subject. The second argument is that each honorific form adds information. Simplifying somewhat, we may say that the more honorifics, the more polite. This is rather different from agreement, which in the canonical situation represents redundant information. Certainly having plural markers on each of a string of attributive modifiers does not indicate anything additional about the number of referents. Kim/Sells (2007) therefore treat the semantics of honorifics in terms of 'expressive meaning', following work by

\footnotetext{
${ }^{4}$ For the restriction of politeness marking by finiteness in Japanese and Korean see Bisang (2007: 128-130).
} 
Potts/Kawahara (2004) and Potts (2005: 179-185). Expressive meaning is separated from propositional meaning, and is incremental in nature.

The important point, then, is that the occurrence of honorific markers at various points in an utterance does not necessarily imply an agreement analysis; this means that some of the languages which were apparently the most likely examples of a morphosyntactic feature RESPECT, such as Korean, prove actually not to be so.

\section{$4 \quad$ Languages with a morphosyntactic feature respect}

And yet we do find languages which appear to require such a morphosyntactic feature. In the clearest cases there is unique morphological material attributable to the feature, and the feature cross-classifies with other morphosyntactic features. Take these data from Muna (an Austronesian language spoken on Muna, off the southeast coast of Sulawesi)

(7) Number and politeness markers in Muna (van den Berg 1989: 51, 82)

\begin{tabular}{|l|l|l|}
\hline 'go' $\left(2^{\text {nd }}\right.$ person $)$ & singular & plural \\
\hline neutral & o-kala & o-kala-amu \\
\hline polite & to-kala & to-kala-amu \\
\hline
\end{tabular}

We see that to- marks polite address, irrespective of number. There are a few other languages where a plausible case can be made for a morphosyntactic feature for RESPECT, including Maithili (Bickel/Bisang/Yādava 1999), Nepali (Bonami/Boyé 2008), Tamil, where the relation to number and the dialect differentiation makes the situation particularly complex (Levinson 1979, Brown/Levinson 1987: 199-201; Schiffman 1999: 115-16); for the development of the Tamil polite forms see Brown/Levinson (1987: 293-294) and Rangan/Suseela (2003), and finally - closer to home linguistically - Bavarian German and Louisiana French (Simon 2007).

Most of these languages were mentioned in Corbett (2006: 137-138), so let us here concentrate on new data. First we examine Kambaata (Treis 2007, especially 2, 55, 304-309, 368369, and personal communications). Kambaata is a Cushitic language of Ethiopia (Highland East Cushitic branch), spoken by something over 600,000 people mainly living in highland areas between the Omo and the Billate rivers, some $300 \mathrm{~km}$ to the southwest of Addis Ababa (see map). ${ }^{5}$

\footnotetext{
5 Found at: http://www.travelblog.org/Africa/Ethiopia/map-of-ethiopia.html, original source: https://www.cia.gov/library/publications/the-world-factbook/geos/et.html, both acessed January 19, 2011.
} 


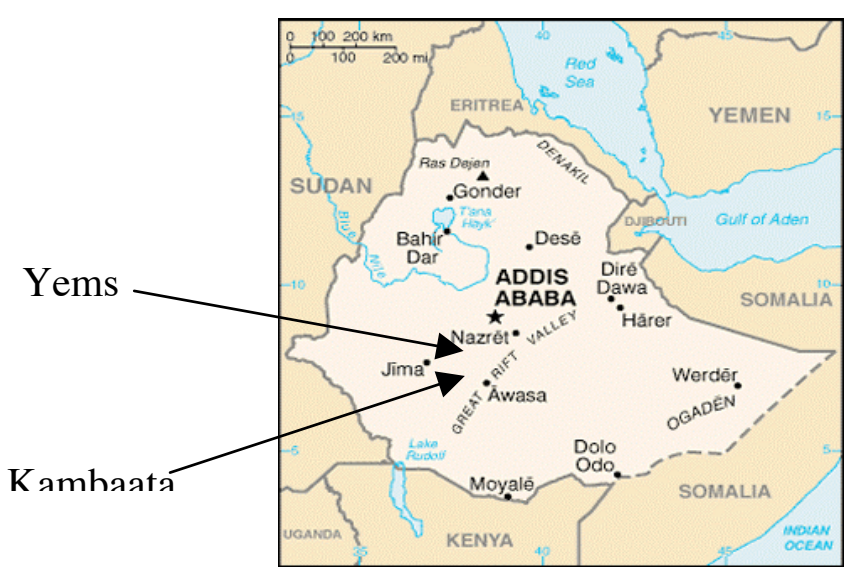

Figure 1: Location of Kambaata and Yemsa in Ethiopia

There are honorific distinctions in the independent personal pronouns, as follows:

(8) Kambaata personal pronouns: nominative case (from Treis 2007: 305)

\begin{tabular}{|l|l|l|}
\hline & SG & PL \\
\hline 1 & án & na'óot \\
\hline 2 & át & \multirow{2}{*}{ a'nno'óot } \\
\cline { 1 - 2 } 2 HON & á'nnu & \\
\cline { 1 - 2 } $3 \mathrm{M}$ & ís (ísu) & \multirow{2}{*}{ isso'óot } \\
\cline { 1 - 2 } $3 \mathrm{~F}$ & íse & \\
\cline { 1 - 2 } $3 \mathrm{HON}$ & íssa & \\
\cline { 1 - 2 } & &
\end{tabular}

Only the nominative is given: the honorific/non-honorific distinctions go through seven cases. This is a recent development: related languages have fewer distinctions, and the development appears to have been stimulated by contact with Amharic (Treis 2007: 306-309); the personal pronouns are regularly dropped. The verb shows fewer distinctions: 
(9) Kambaata perfective paradigm zat- 'become meager' (from Treis 2007: 369)

\begin{tabular}{|l|l|l|}
\hline & SG & PL \\
\hline 1 & zachch-óo-m(m) & zantóo-m(m) \\
\hline 2 & zat-tóo-nt & zat-téen-Ø-ta(a'u) \\
\cline { 1 - 2 } $3 \mathrm{M}$ & záchch-o & \multirow{2}{*}{ zat-tóo-'u } \\
\hline 3 F & zat-tóo-'u & \\
\cline { 1 - 2 } 3 HON/GNRC & zat-éem- $\varnothing$-ma(a'u) & \\
\hline
\end{tabular}

Note that the third plural is syncretic with the third feminine singular. The correspondences with the pronouns are discussed in turn. The second person honorific pronoun takes a second person plural verb:

Kambaata (Treis 2007: 305)
Ánnu
kánne
ang-á-'nne
2HON.NOM
DEM.PRON.PROX.M.OBL
hand-F.ACC-2PL.POSS
$\begin{array}{llll}\text { barg-iteenán-iyan } & \text { án } & \text { ká'e } & \text { kaa'll-áamm. } \\ \text { add-2PL.IPFV.CVB-DS } & \text { 1SG.NOM } & \text { DEM.PRON.CNTR.M.OBL help-1SG.IPFV }\end{array}$
'While you (HON) are helping here, I will help there.'

Note how this differs from more familiar languages: though the plural verbal form is used for polite address, it does so in agreement with a unique pronoun.

The third person honorific pronoun has a form distinct from the plural in any verbal paradigm, and is of particular interest. Treis uses the gloss 'HON', which she expands as 'honorific', and 'impersonal' (impersonal in the German sense, for generic or non-specific, as for French on or German man). I have given a double gloss in (9) and (11), to stress that these third person honorific verb forms have two functions (Treis 2007: 305); they are used for reference to a single respected person, and in generic or non-specific use ('one'):

Kambaata (Treis 2007: 305)

Qeer-s-éen

moog-éenno.

become.deep-CAUS1-3HON/GNRC.PFV.CVB bury-3HON/GNRC.IPFV

(i) 'One buries it deep.'

(ii) 'S/he [a respected old man / woman mentioned before] buries it deep.'

The honorific pronoun is unambiguous however; when it is present, only the honorific reading is possible. 
Since we are considering whether HONORIFIC is a possible feature, we should take the most cautious analysis. We would say that the verb forms in examples like (11) are simply generic/non-specific. They can be used straightforwardly in this function, or with an honorific third person pronoun. Then, just as the second person honorific pronoun has a special requirement, namely that the verb be plural, so the third person honorific pronoun is also special: it requires a generic/non-specific verb. (And this makes sense, since it is another type of the avoidance discussed in §2.) We now have two pronouns, the second and third persons honorific, which have a similar function, and require specific agreement effects. We could then say that the agreement rules of Kambaata have to refer to a feature RESPECT, showing it to be a morphosyntactic feature, though one with only a small toe-hold in the paradigm. Indeed its status is particularly interesting. It has no unique form, but uses the plural form in the second person and that of the generic/non-specific in the third person. While non-autonomous values are well-known (see Zaliznjak 1973: 69-74, Corbett 2010), a feature with no autonomous forms is rare; the example of person in Archi is analysed in Chumakina/Kibort/Corbett (2007).

For a clearer claim for a morphosyntactic feature RESPECT we move to Yemsa, an Omotic language with over 80,000 speakers in the Oromo region of Ethiopia. The data are from Silvia Zaugg-Coretti, personal communications. Here are some relevant parts of the verb inflections (note that distinctions may be marked by tone, and that there are some syncretisms, and that gender is distinguished in the second singular, but only in the imperative, and the markers are optional). 
(12) Yemsa verbal paradigms (partial): Silvia Zaugg-Coretti (p.c.)

\begin{tabular}{|c|c|c|c|}
\hline & Perfective & Future & Jussive/Imperative \\
\hline $1 \mathrm{SG}$ & $-n$ & -nā-r & $-n \bar{a}$ \\
\hline $2 \mathrm{SG}$ & $-\mathrm{t}$ & $-t \bar{a}-\mathrm{r}$ & (-wè/-wā (F/M)) \\
\hline 2SG HON & $-n \overline{1}$ & $-n \overline{1}-\mathrm{r}$ & -nì \\
\hline $3 \mathrm{SG} \mathrm{F}$ & $\varnothing$ & $-n \overline{1}-\mathrm{r}$ & $-n$ \\
\hline 3SG M & $\varnothing$ & -nŭ-r & -ò \\
\hline 3SG HON & $-\mathrm{te}$ & $-n \bar{e}-r$ & -tó \\
\hline 1PL & $-n \overline{1}$ & $-n \overline{1}-\mathrm{r}$ & -nī \\
\hline 2PL & $-\mathrm{t} \overline{\mathrm{1}}$ & $-\mathrm{t} \overline{\mathrm{i}}-\mathrm{r}$ & -tì \\
\hline 2PL HON & -sé-n̄̄ & -só-nī-r & -sō-nì \\
\hline 3PL F & -sé & -ō-nī-r & -ò-n \\
\hline 3PL M & -sé & -ō-nй-r & -ò-ó \\
\hline 3PL HON & -sé-tē & -só-nē-r & -só-tó \\
\hline
\end{tabular}

The significant point for our purposes is the intersection of number and respect. The plural of forms of the polite singulars, and of the third person forms, are like the singular but with a plural suffix $-(s) e$ (realis) or $-(s) o$ (irrealis). 


\begin{tabular}{|l|l|l|}
\hline & SG & PL \\
\hline 1 & tá & $\overline{1} n n o ̄$ \\
\hline 2 & ně & nìttō \\
\hline 2 HON & nì & nìnò \\
\hline $3 \mathrm{~F}$ & bàr & bārīkītō \\
\hline $3 \mathrm{M}$ & băr & băsākìtò \\
\hline $3 \mathrm{HON}$ & bààs & bààssò \\
\hline
\end{tabular}

These pronouns are used for emphasis. Note that the third person masculine and feminine plural pronouns show nominal forms regularly formed from the singular (Silvia Zaugg-Coretti p.c.). Again we should concentrate on the intersection of number and respect, which in combination with the verb paradigm suggests the need for a morphosyntactic feature here.

Still following Silvia Zaugg-Coretti (personal communication), there are at least 100 lexemes which have different counterparts according to politeness. Formerly there were three politeness registers: royal, polite and common, but no longer having a king anymore, speakers of Yemsa are reduced to two (see also Wedekind 1986).

These examples indicate that there are languages where we need a morphosyntactic feature RESPECT in order to account for the forms attested. These languages are few, constituting a small subset of those where politeness considerations are important to account for the linguistic system.

\section{Why is the morphosyntactic feature respect so rare?}

Given this evidence suggesting that there can be a feature for respect, we may ask why it occurs only rarely. I suggest three possible types of factor:

We might argue that a discrete set of feature values is not appropriate for gradient behaviour. I had earlier rejected this motivation, since pronoun choice for respect is precisely selection from a small set (typically 'be polite' or 'do not'). However, the detailed argumentation in Kim/Sells (2007) makes this motivation look much more plausible again, since they show how in more extended systems the effect of honorific markers is additive. 
Respect does not intersect with other features with equal readiness. This may be a factor, but the argument is not fully convincing, since clusivity is even more restricted in its interaction (with first person), and yet morphosyntactic clusivity is widespread. ${ }^{6}$

The rapid change associated with politeness systems may disfavour the development of a morphosyntactic feature.

I think these ideas are worth pursuing, looking carefully at other 'potential' features, in the hope that the special situation of respect will shed light on the larger question of why we find a relatively small inventory of morphosyntactic features in the world's languages. (A recent discussion of the wider question of possible grammatical categories can be found in Bisang 2007: 130-134, following work by Talmy 1985: 126-138 and Slobin 2001.)

\section{A comparison: the diminutive}

It is worth considering whether there is any other potential feature with similar characteristics. There are arguably several points of comparison with the diminutive:

- like politeness markers, diminutives are found in many languages.

- just as honorifics may be supplemented by humilifics, so languages with diminutives may also have augmentatives (typically a less elaborated system).

- diminutives frequently convey expressive meaning, such as endearment (see Jurafsky 1996 for the semantics of the diminutive, and Dressler/Barbaresi 1994 for abundant examples).

- as for politeness, the expressive meaning of diminutives is incremental in nature.

Given this, it is worth considering the status of the diminutive, for comparison. We may find repeated expression of diminutives; an example is Russian, where we may find diminutive marking on adjectives as well as nouns. However, this is not agreement. Rather the speaker has adopted a familiar and endearing attitude, which may be expressed at different points in the utterance. Thus we find repeated expression as a reflection of the same effect through the utterance (which gives a distant analogy to the Kim/Sells 2007 account of Korean honorifics, and not to an agreement system) ${ }^{7}$

\subsection{Different types of diminutive}

What then are the characteristics of the diminutive relevant for our argument? It may serve as a factor in gender assignment. For instance, in Archi there is an opposition between larger and smaller (both for animals and inanimates), with larger tending to be assigned to gender III and smaller to gender IV (Kibrik, Kodzasov, Olovjannikova/Samedov 1977: 55-66; Corbett 1991: 27-29, 31). ${ }^{8}$ This is just one of several criteria which have an effect on gender assignment in Archi. There is no question of proposing a feature DIMINUTIVE here. A slightly stronger case might be made for the Omotic language Dizi. Here the feminine gender comprises nouns denoting females and diminutives; all others are masculine (Allan 1976; Corbett 1991: 11).

\footnotetext{
6 This depends, however, on one's view of CLUSIVITY; see Bobaljik (2008) for recent discussion and references.

7 The comparison is complicated by the various unusual properties of diminutives; see, for instance, Stump (1993), and especially Stump (2001: 99-119 passim) for examples of diminutives as head marked, notably in Breton. Another point we should keep in mind is that in several languages (Russian is a good example) diminutives are particular common on personal names, giving a range of degrees of familiarity. They thus overlap with politeness considerations. A remarkable instance is provided by certain Polish dialects (Zaręba 1984-85, Corbett 1991: 100-101).

8 This recalls instances like German Mädchen 'girl'; note, however, that there is an additional complication here. While such nouns are often described as neuter, they are hybrids, since they taken neuter agreement within the noun phrase, but can take feminine anaphoric pronouns.
} 
Diminutive has a greater role in the assignment of nouns to gender, but this does not require us to propose a morphosyntactic feature.

Now consider Chichewa, a Bantu language of Malawi:

Chichewa (Corbett/Mtenje 1987: 5)

(14)

$\begin{array}{lll}\text { ka-mwana ka-li } & \text { bwino } \\ \text { G7.SG-infant } & \text { G7.SG-be } & \text { in.good.order } \\ \text { 'the infant is well' } & \end{array}$
ti-ana
ti-li
bwino
G7.PL-infant G7.PL-be in.good.order
'the infants are well'

The 'G7' gloss indicates one of Chichewa's seven genders (additionally there are three "locative" genders). It has unique agreement markers, $k a$ - and $t i$-, as shown in $k a$-li and $t i-l i$ above, and there is no reason not to treat it as a gender value. It has some distinguishing characteristics, however. First, there are relatively few items that belong only in this gender; most members are nouns derived from nouns in other gender values. Typically they retain their original prefix ( $m u$ - in mwana) and add the diminutive prefix. This is a common picture in Bantu (Schadeberg 2003: 83, who notes that generally the few nouns inherently in this gender have no obvious semantics of 'smallness'). Second, there are minor complications with the agreements (Corbett/Mtenje 1987: 11-12, 31,33,36), which are related to the fact that the gender has a closer link to semantics than most of Chichewa's other genders. In Chichewa, then, diminutive is relevant to syntax (agreement); diminutives are grouped into a gender, whose agreements intersect with number. The morphosyntax of Chichewa needs to refer to diminutive, but as the value of the feature GENDER, and not as a morphosyntactic feature in its own right.

The best case for a morphosyntactic feature diminutive comes from Walman, a Torricelli language of Papua New Guinea. The information comes from an interesting paper by Brown/Dryer (ms.), and I thank them for discussion of its significance. Ultimately, while the system is remarkable and challenging, I would still argue that we do not need to recognize a separate feature here (and therefore that we should not). Consider first these data:

Walman: (Brown/Dryer ms.)

(16) Pelen n-aykiri.

dog 3SG.M-bark

'The male dog is barking.'

(17) Pelen w-aykiri.

dog 3sG.F-bark

'The female dog is barking.'

(18) Pelen 1-aykiri.

dog 3sG.DIMIN-bark

'The puppy is barking.'

(19) Pelen y-aykiri.

dog 3PL-bark

'The dogs are barking.'

The four different agreement markers are clearly distinct, and they appear regularly on a range of different targets, including personal pronouns, sometimes as prefixes, sometimes as 
suffixes, even as infixes. These markers suggest that we have inflectional number and gender. Let us take the interesting properties of the Walman diminutive one at a time:

- cross-linguistically, diminutive is commonly marked on nouns, and less often on other parts of speech. However, in Walman it appears that a lack of overt marking on nouns is generally found with gender and number, as the examples suggest.

- the diminutive is distributed like the masculine and feminine genders, in that each is indicated only in the singular. (18) is appropriate only if one puppy is barking (but see below for a complication). Note that (18) is glossed as 'puppy', and not as 'small dog': with animates the diminutive is used for the young, not for small members of the species.

- the examples with pelen 'dog' give an instance where each gender is available. However, there are nouns which belong just to one gender, such as ngolu 'cassowary', which is grammatically masculine, irrespective of sex. There are therefore nouns which are masculine (with diminutive also possible), others which are feminine (with diminutive also possible), those like pelen 'dog' which can take masculine, feminine or diminutive agreements. But there are no nouns which are in the diminutive gender.

- the diminutive is never obligatory (while, for instance, the plural is required for a plural referent). Thus (17) could be uttered appropriately of a puppy; however, this is not too surprising, since any puppy is a dog, and any small object is an instance of the general case.

- we might suggest that we are dealing with derivation of nouns (but without overt markers). However, we find examples of masculine or feminine agreement together with diminutive agreement for the same controller in the same clause. There are two interesting points here. First, we do not find masculine and feminine agreement together (Brown/Dryer treat this as a significant difference of the diminutive, but it could simply follow from semantic incompatibility). Second, while masculine or feminine do not co-occur with plural, and the diminutive normally does not, it may do so just for pluralia tantum nouns, which are semantically singular.

- the diminutive forms often imply endearment (as is frequently the case for diminutives cross-linguistically).

Where does this leave us? Brown/Dryer (ms.) rightly make the comparison with a Bantu language, and conclude that the diminutive in Bantu is a gender while that of Walman is inflectional, but is not a gender. I find their fieldwork and analysis highly interesting, but I suggest that their conclusion need not follow. We need not think of being a gender or not as a black/white issue. The diminutive in Walman is a long way from being a canonical gender; nevertheless, it shares characteristics with genders both in Walman and in other gender systems. Specifically: gender can be tightly determined by semantics, as in Dravidian languages like Tamil. Gender can be covert on nouns. This is found in Savosavo, the easternmost Papuan language. This language is particularly relevant: it has two genders, inanimates are by default masculine, but can be switched to the feminine (with no marker on the noun), to give the effect of a diminutive or to show that the referent is special in some other way (Wegener 2008: 64-67). Thus switching of genders is attested elsewhere. The Walman interaction with number (gender distinguished only in the singular) is commonplace, being shared with German and Russian among other languages. Genders with few nouns are attested (Corbett 1991: 173-175), and this is found with the diminutive genders in several Bantu languages, as we noted early. A complete mismatch of controller and target genders, that is, a gender marked on agreement targets but having no controller noun members is unusual, but is found (for a different type of gender) in Surselvan Romansh, for example (Corbett 2010). Thus we can reasonably treat the Walman diminutive as a (very non-canonical) gender; the alternative, to 
propose a new morphosyntactic feature, is one that Ockham would not approve of. That said, the data are of special interest. ${ }^{9}$

\subsection{The comparison with respect}

Returning to our comparison with respect, we see that diminutive, like respect, struggles to reach the status of a morphosyntactic feature. Diminutive does reach the status of being a value, of the feature GENDER. On the other hand respect appears to achieve the status of a morphosyntactic feature, intersecting with other morphosyntactic features, but only very rarely. Perhaps when sufficient examples have been gathered it will prove possible to show here that, as with diminutive, RESPECT can be seen as a value of another feature.

A further point of comparison between the 'best' instances of respect and of diminutive is their course of development. Both have arisen by 'converting' the value of a morphosyntactic feature. Treiss (2007: 306-308) shows how the honorific forms of Kambaata have arisen from a number form, and Brown/Dryer (ms.) show how the diminutive in Walman arises from an earlier neuter gender.

How then do our possible reasons for the rareness of a morphosyntactic feature respect fare when we look at diminutive? Let us recall each in turn.

We might argue that a discrete set of feature values is not appropriate for gradient behaviour. This argument has some force in respect of the affective use of diminutive, but hardly for its neutral use.

Diminutive does not intersect with other features with equal readiness. This is true, and suggests this argument may be stronger than it first appeared.

Rapid change may disfavour the development of a morphosyntactic feature; there is no relevant supporting evidence here.

The comparison of these arguments for the very limited success of diminutive and respect as morphosyntactic features suggests that ease of intersection with other features may be significant. RESPECT does not intersect with other features with equal readiness. The first argument, that discrete feature values are not appropriate may also have some force, when combined with the issue of intersection. Even if RESPECT can intersect with the second person (using a mechanism to select one of a discrete set of values to show appropriate politeness to an addressee), this may be less readily achievable for the wide range of possible third persons. ${ }^{10}$

\section{$7 \quad$ Conclusion}

Politeness is of enormous importance in language; the impact it can have on the linguistic system can go well beyond anything we might have expected. And yet though ubiquitous in some languages it rarely gains the status of a genuine morphosyntactic feature. I proposed possible reasons for this, but there is as yet insufficient relevant evidence to consider them convincing. Here the comparison with diminutives is suggestive. I think these ideas are worth pursuing, looking carefully at other 'potential' features, in the hope that the special situation of

\footnotetext{
${ }^{9}$ Munro (1988) discusses the optional diminutive marker in Lakhota (Siouan), the Oklahoma Seminole dialect of Creek and Chickasaw (both Muskogean), and Maricopa (Yuman). Conditions on its appearance vary ('the best time to elicit syntactic diminutives or hear them spontaneously produced is when a baby is present.' Munro 1988: 540), but the common requirement is an appropriate argument of the verb. Chickasaw has the strictest rule: only a surface subject can license the diminutive. The status of this marker is fascinating: it is optional and does not stand in opposition to any other value; it has not yet achieved the status of a feature. Pamela Munro suggests (personal communication) that it resembles an honorific.

10 And as Bob Hoberman points out (personal communication), there is considerably lower motivation to be polite to third persons if they are not present to hear the effort made for them.
} 
respect will shed light on the larger question of why we find the relatively small inventory of morphosyntactic features that we do in the world's languages.

\section{References}

Allan, Edward J. (1976): "Dizi". In: Bender, Lionel M. (ed.): The Non-Semitic Languages of Ethiopia. East Lansing, African Studies Center, Michigan State University: 377-392.

Alpatov, V. M. (1973): Kategorija vežlivosti v sovremennom japonskom jazyke. Moscow: Nauka.

Baerman, Matthew (2006): "Basque". In: Corbett, Greville G./Baerman, Matthew/Brown, Dunstan/Hippisley, Andrew (eds.): Cross-linguistic Deponency Database. Available at: http://www.smg.surrey.ac.uk/deponency/WALS/Basque.htm, accessed January 19, 2011.

Berg, René van den (1989): A Grammar of the Muna Language. Dordrecht: Foris. (= Verhandelingen van het Koninklijk Instituut voor Taal-, Land- en Volkenkunde 139).

Bickel, Balthasar/Bisang, Walter/ Yādava, Yogendra P. (1999): "Face vs. empathy: the social foundation of Maithili verb agreement". Linguistics 37: 481-518.

Bisang, Walter (2007): "Categories that make finiteness: discreteness from a functional perspective and some of its repercussions". In: Nikolaeva, Irina (ed.): Finiteness: Theoretical and empirical foundations. Oxford, Oxford University Press: 115-137.

Bobaljik, Jonathan D. (2008): "Missing persons: A case study in morphological universals". The Linguistic Review 25: 203-230.

Bobaljik, Jonathan/Yatsushiro, Kazuko (2006): "Problems with honorification-as-agreement in Japanese: A reply to Boeckx \& Niinuma". Natural Language and Linguistic Theory 24: 355-384.

Boeckx, Cedric/Niinuma, Fumikazu (2004): "Conditions on agreement in Japanese". Natural Language and Linguistic Theory 22: 453-80.

Bonami, Olivier/Boyé, Gilles (2008): "Paradigm shape is morphomic in Nepali". Paper read at the 13th International Morphology Meeting, Vienna.

Brown, Lea/Dryer, Matthew (s.a.): "Diminutive as an inflectional category in Walman". University at Buffalo, manuscript. Available at:

linguistics.buffalo.edu/people/faculty/dryer/dryer/BrownDryerWalmanDimin.pdf, accessed January 19, 2009.

Brown, Penelope/Levinson, Stephen C. (1987): Politeness: Some universals in language usage. Cambridge: Cambridge University Press. $(=$ Studies in Interactional Sociolinguistics 4).

Choi, Incheol (2003): "A constraint-based approach to Korean partial honorific agreement". In: Griffin, William E. (ed.): The Role of Agreement in Natural Language: TLS 5 Proceedings: 157-66. Available at: http://uts.cc.utexas.edu/ tls/2001tls/2001proceeds.html, accessed January 19, 2011.

Chumakina, Marina/Kibort, Anna/Corbett, Greville G. (2007): "Determining a language's feature inventory: person in Archi". In: Austin, Peter K./Simpson, Andrew (eds.): Endangered Languages. Hamburg, Helmut Buske: 143-172. (= Linguistische Berichte Sonderheft 14).

Comrie, Bernard (1975): "Polite plurals and predicate agreement". Language 51: 406-418.

Comrie, Bernard (1976): "Linguistic politeness axes: Speaker-addressee, speaker-referent, speaker-bystander". Pragmatics Microfiche 1.7: A3-B1. Oxford: Oxford Microform.

Corbett, Greville G. (1983): Hierarchies, Targets and Controllers: Agreement patterns in Slavic. London: Croom Helm.

Corbett, Greville G. (1991) Gender. Cambridge: Cambridge University Press.

Corbett, Greville G. (2000): Number. Cambridge: Cambridge University Press.

Corbett, Greville G. (2006): Agreement. Cambridge: Cambridge University Press. 
Corbett, Greville G. (2011): "The penumbra of morphosyntactic feature systems". In: Bobaljik, Jonathan/Sauerland, Uli/Nevins, Andrew (eds.): Markedness and Underspecification in the Morphology and Semantics of Agreement. Special issue Morphology 21/2: 445-80.

Corbett, Greville G. (forthcoming): Features. Cambridge: Cambridge University Press.

Corbett, Greville G./Mtenje, Alfred D. (1987): "Gender agreement in Chichewa". Studies in African Linguistics 18: 1-38.

Dixon, Robert. M. W. (1980): The Languages of Australia. Cambridge: Cambridge University Press.

Dressler, Wolfgang U./Barbaresi, Lavinia Merlini (1994): Morphopragmatics: Diminutives and Intensifiers in Italian, German, and Other Languages. Berlin: Mouton de Gruyter.

Evans, Nicholas/Brown, Dunstan/Corbett, Greville G. (2001): "Dalabon pronominal prefixes and the typology of syncretism: a Network Morphology analysis". In: Booij, Geert/van Marle, Jaap (eds.): Yearbook of Morphology 2000. Dordrecht, Kluwer: 187-231.

Findreng, Ådne (1976): Zur Kongruenz in Person und Numerus zwischen Subjekt und finitem Verb im modernen Deutsch. Oslo: Universitetsforlaget.

Foley, William A. (1986): The Papuan Languages of New Guinea. Cambridge: Cambridge University Press.

Geertz, Clifford. (1960): The religion of Java. Glencoe, Ill.: Free Press. (The relevant chapter is "Linguistic etiquette", pp. 248-260, and this is reprinted in: Fishman, Joshua A. (ed.) (1968): Readings in the Sociology of Language. The Hague, Mouton: 282-295.).

Heath, Jeffrey (1991): "Pragmatic disguise in pronominal-affix paradigms". In: Plank, Frans (ed.): Paradigms: the economy of inflection. Berlin, Mouton de Gruyter: 75-89.

Heath, Jeffrey (1998): "Pragmatic skewing in $1<->2$ pronominal combinations in Native American languages". International Journal of American Linguistics 64: 83-104.

Helmbrecht, Johannes (2005): "Politeness distinctions in pronouns". In: Haspelmath, Martin/Dryer, Matthew S./Gil, David/Comrie, Bernard (eds.): The World Atlas of Language Structures. Oxford, Oxford University Press: 186-189.

Hualde, José Ignacio/Oyharçabal, Beñat/de Urbina, Jon Ortiz (2003): "Verbs". In: Hualde, José Ignacio/de Urbina, Jon Ortiz (eds.): A grammar of Basque. Berlin, Mouton de Gruyter: 195-246.

Khaidakov, S. M. [Xajdakov, S. M.] (1963): "Principy raspredelenija imen suščestvitel’nyx po grammatičeskim klassam v lakskom jazyke". Studia Caucasica 1: 48-55.

Khaidakov, S.M. (1980): Principy imennoj klassifikacii v dagestanskix jazykax. Moscow: Nauka.

Jurafsky, Daniel (1996): "Universal tendencies in the semantics of the diminutive". Language 72: 533-78.

Kibrik, A. E. (1977): Opyt strukturnogo opisanija arčinskogo jazyka: II: Taksonomičeskaja grammatika. Moscow: Izdatel'stvo Moskovskogo universiteta. (Publikacii otdelenija strukturnoj i prikladnoj lingvistiki 12).

Kibrik, A. E./Kodzasov, S. V./Olovjannikova, I. P./Samedov, D. S. (1977): Opyt strukturnogo opisanija arčinskogo jazyka: I: Leksika, fonetika. Moscow: Izdatel'stvo Moskovskogo universiteta. (= Publikacii otdelenija strukturnoj i prikladnoj lingvistiki 11).

Kim, Jong-Bok/Sells, Peter (2007): "Korean honorification: a kind of expressive meaning". Journal of East Asian Linguistics 16: 303-336.

Kim, Jong-Bok/Sells, Peter/Yang, Jaehyung (2006): "Parsing Korean honorification phenomena in a typed feature structure grammar". In: Advances in Artificial Intelligence: Proceedings of the 19th Conference of the Canadian Society for Computational Studies of Intelligence, Canadian AI 2006, Québec City, Québec, Canada, June 7-9, 2006. (Lecture Notes in Computer Science Volume 4013/2006). Berlin, Springer: 254-265. [DOI: 10.1007/11766247]. 
Levinson, Stephen C. (1979): "Pragmatics and social deixis: reclaiming the notion of conventional implicature". In: Chiarello, Christine (ed.): Proceedings of the Fifth Annual Meeting of the Berkeley Linguistics Society. Berkeley, CA, Berkeley Linguistics Society: 206-223.

Munro, Pamela (1988): "Diminutive syntax". In: Shipley, William (ed.): In Honor of Mary Haas: From the Haas Festival Conference on Native American Linguistics. Berlin, Mouton de Gruyter: 539-556.

Munrso, Pamela (2002): "Hierarchical Pronouns in Discourse: Third Person Pronouns in San Lucas Quiaviní Zapotec Narratives". Southwest Journal of Linguistics 21: 37-66.

O'Neil, P. G. (1966): A Programmed Course on Respect Language in Modern Japanese. London: English Universities Press and School of Oriental and African Studies.

Pollard, Carl/Sag, Ivan A. (1994): Head-Driven Phrase Structure Grammar. Chicago: University of Chicago Press.

Potts, Christopher (2005): The Logic of Conventional Implicatures. Oxford: Oxford University Press. (= Oxford Studies in Theoretical Linguistics 7).

Potts, Christopher/Kawahara, Shigeto (2004): "Japanese honorifics as emotive definite descriptions". In: Watanabe, Kazuha/Young, Robert B. (eds.): Proceedings of the Fourteenth Conference on Semantics and Linguistic Theory (SALT). Ithaca, NY, CLC Publications: 253-270.

Rangan, K./Suseela, M. (2003): "A comparison of agreement system in Old Tamil and Modern Tamil". In: Reddy, B. Ramakrishna (ed.): Agreement in Dravidian Languages. Chennai, International Institute of Tamil Studies: 28-50.

Rombandeeva, E. I. (1973): Mansijskij (vogul'skij) jazyk. Moscow: Nauka.

Schadeberg, Thilo C. (2003): "Derivation". In: Nurse, Derek/Philippson, Gérard (eds.): The Bantu languages. London, Routledge: 71-89. (= Routledge language family series 4).

Schiffman, Harold F. (1999): A Reference Grammar of Spoken Tamil. Cambridge: Cambridge University Press.

Simon, Horst J. (2007): "Wie Höflichkeit die Person(en) verwirrt - und wie's die Grammatik wieder ordnet". In: Behr, Irmtraud/Larrory, Anne/Samson, Gunhild (eds.): Der Ausdruck der Person im Deutschen. Tübingen, Stauffenburg: 57-72. (= Eurogermanistik 24).

Slobin, Dan I. (2001): "Form-function relations: how do children find out what they are?" In: Bowerman, Melissa/Levinson, Stephen C. (eds.): Language acquisition and conceptual development. Cambridge, Cambridge University Press: 406-449.

Stump, Gregory T. (1993): "How peculiar is evaluative morphology?" Journal of Linguistics 29: $1-36$.

Stump, Gregory T. (2001): Inflectional Morphology: A Theory of Paradigm Structure. Cambridge: Cambridge University Press.

Talmy, Leonard (1985): "Lexicalization patterns: semantic structure in lexical form". In: Shopen, Timothy (ed.): Language Typology and Syntactic Description, Vol. III: Grammatical Categories and the Lexicon. Cambridge, Cambridge University Press: 57149.

Treis, Yvonne (2005): "Avoiding their names, avoiding their eyes: how Kambaata women respect their in-laws". Anthropological Linguistics 47: 292-320.

Treis, Yvonne (2007): Towards a Grammar of Kambaata: Phonology, Nominal Morphology, and Non-verbal Predication. $\mathrm{PhD}$ thesis, University of Cologne. [Since published 2008].

Wedekind, Klaus (1986): "Communication breakdown or lèse-majesté: How feudoid subgroups of the Yemma (Janjero) talk to each other". In: Elson, Benjamin F. (ed.): Language in global perspective: Papers in honor of the 50th anniversary of the Summer Institute of Linguistics, 1935-1985. Dallas, Summer Institute of Linguistics: 557-562.

Wegener, Claudia (2008): A grammar of Savosavo: a Papuan language of the Solomon Islands. PhD thesis, Radboud University, Nijmegen. (= MPI series in psycholinguistics). 
Wetzel, Patricia J. (2004): Keigo in Modern Japan: Polite language from Meiji to the present. Honolulu: University of Hawai'i Press.

Zaliznjak, Andrej A. (1973): "O ponimanii termina 'padež' v lingvističeskix opisanijax". In: Zaliznjak, Andrej, A. (ed.): Problemy grammatičeskogo modelirovanija. Moscow, Nauka: 53-87. [Reprinted in: Zaliznjak, Andrej A. (2002): Russkoe imennoe slovoizmenenie: $s$ priloženiem izbrannyx rabot po sovremennomu russkomu jazyku i obščemu jazykoznaniju. Moscow, Jazyki slavjanskoj kul'tury: 613-47].

Zaręba, Alfred (1984-85): "Osobliwa zmiana rodzaju naturalnego w dialektach polskich". Zbornik Matice srpske za filologiju i lingvistiku 27-28: 243-247. 